\title{
Early Career Teachers' Experiences of Communicating with Families via Technology: Educatively Dwelling in Tension
}

\author{
Nathalie Reid, Joanne Farmer, Claire Desrochers, and Sue McKenzie-Robblee
}

\section{University of Alberta}

\begin{abstract}
A variety of online programs, apps, and digital learning management systems currently "provide teachers with a means to more easily communicate and share information with students and parents through discussion forums, social media, videoconferencing, email, grade books, and announcements" (Howell \& O'Donnell, 2017, p.28). While technology is often seen as shaping positive shifts in teachers' and schools' abilities to communicate with families, we, the five coresearchers in the study Understanding the Interactions Between Early Career Teachers and Families, wondered how early career teachers were experiencing the use of technology to interact with families. During semi-structured interviews with each of the 20 teacher participants, we were awakened, for example, to tensions experienced by many of the teachers when expectations to communicate with families electronically conflicted with their longings for more relational and reciprocal interactions. Yet, we also came to see that the teachers were learning to dwell in these tensions in ways that opened potential for educative (Dewey, 1938) growth and movement toward the kinds of interactions with families they were imagining. This paper takes up technology as one of the resonant threads drawn from and across the teachers' storied experiences, and inquires narratively into the kinds of generative tensions that many of the teachers were experiencing and drawing on as they imagined increased relational and reciprocal ways of interacting with families, and then moves to wonder how dwelling in these tensions might shape preservice and in-service teacher education.
\end{abstract}

Keywords: Early career teachers; families; technology; interactions; agency

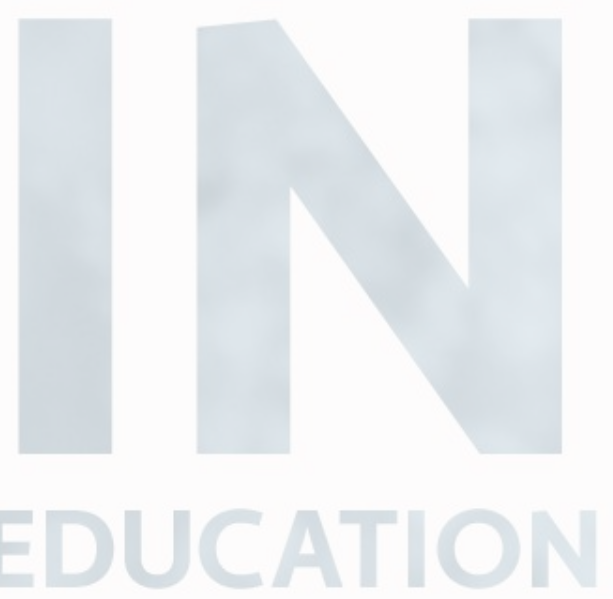




\title{
Early Career Teachers' Experiences of Communicating with Families via Technology: Educatively Dwelling in Tension Beginning in Experience
}

\author{
You have updates, report cards, there's so much documentation \\ and so much time put on the computer \\ that it's been difficult to make the phone calls, \\ make the continuous, constant connections.
}

(Interview with Mrs. Lee ${ }^{1}$ )

I'll get emails at 10 o'clock at night, I'll get emails on the weekend, I'll get emails all the time.

A lot of the teachers at our school are younger

and a lot of them don't have children and

they have a very different perspective on things.

I find if I talk to them they think I'm crazy anyways.

They think I'm crazy that I communicate that much with parents.

(Interview with Dawn)

Technology wise, I've been using ContactsSchool, ${ }^{2}$

although I've looked at my stats of parents

who are actually using ContactsSchool and it's extremely low.

I guess it's because we have such a high ESL population, maybe they don't have access to computers,

but I stopped using ContactsSchool now because I realized no one's reading it.

So I have gone back to handing out newsletters in paper

to parents at the beginning of the month

with a calendar of all of our important dates,

and then in their agendas I have labels or stickers because the kids can't write,

just updating them of what's going on in the classroom.

(Interview with Sandra)

The above fragments of experience were shared by three of the 20 urban teachers of Kindergarten to Grade 6 who participated in the study, Interactions Between Early Career Teachers and Families (Huber, Reid, Farmer, Desrocher, \& McKenzie-Robblee, 2017). As coresearchers for this study, we began the inquiry carrying multiple wonders shaped by our own experiences interacting with teachers and families as mothers, grandmothers, daughters, graduate students, teachers, a principal, teacher educators, and researchers. Our shared wonder about the situations in which teachers learn to interact with families became the focus of the study, in part because both our lived experiences and the literature review we completed at the study's onset, seemed to indicate that interactions between teachers and families is not presently a focus of most preservice teacher education programs.

We designed the study's semi-structured interview protocol to draw forward situations, across time and place, in personal and professional contexts that shape and reshape the knowledge teachers draw on as they interact with families, and to learn how teachers' experiences in these situations shape and reshape their interactions with families. Each of the 20 participants were invited to the study through various means: ${ }^{3}$ some through personal contacts, others through the network sustained at the Research Issues Table at the University of Alberta, 
some through letters of invitation sent through the school divisions' main offices, and others yet through information letters sent to principals. The one to two hour-long interviews were recorded and transcribed, and after being reviewed by the teachers for accuracy, we began a year-long process of reading and rereading the transcripts and engaging in weekly research conversations.

Our thoughts returned to our recently completed study when we read in education's call for articles for its special edition on teacher education and teaching. As we began to imagine a new inquiry into the teachers' storied experiences. Mrs. Lee's, Dawn's, and Sandra's experiences seemed to particularly resonate with the theme of in education's special edition, especially in relation with the sub-topics: "Teacher education: preservice, in-service, and professional development [and] Critical concerns related to teaching and learning, for example, ethical relationships." While this thread wove through and between many of the teachers' stories, we chose to foreground Mrs. Lee's, Dawn's, and Sandra's experiences as they made visible their tensions in relation with digital platforms and communication technologies, which they each storied as having the potential to support their interactions with families, but that each also storied as potential barriers to the more relational and reciprocal interactions with families that they were striving and/or longing for.

Sandra, for example, wondered about the division-wide digital learning platform she had been mandated to use by her employing school division, which she learned was not meeting the needs of the families with whom she was in relation. Mrs. Lee expressed tension-filled wonders about the amount of time that was needed to maintain and update the mandated digital learning platform in her school division, which left her little time to interact with families in ways she imagined would be more relational. For Dawn, whose digital interactions with families were extensive, the pervasiveness of technology, which made her accessible to families at all times, was a source of tension in her relationships with colleagues, particularly when her colleagues had different views of how often and when to communicate with families via technology.

In this article, we inquire into wonders and tensions that arose for Mrs. Lee, Dawn, and Sandra in relation with their technology mediated interactions with families. We think narratively ${ }^{4}$ with their stories to open spaces to further wonder about ways in which the tensions they experienced shaped, and reshaped, their teacher identities, senses of agency, teaching practices, and understandings of reciprocal, ethical relationships with families. We close the article by imagining ways in which spaces may be opened teacher education that support preservice teachers, teacher educators, in-service teachers, and those responsible for shaping professional development, to inquire into tensions educatively (Dewey, 1938) and to imagine the potential of such an opening for shaping interactions.

\section{Situating the Chapter}

For the initial study we undertook an extensive literature review to situate our work in an already complex landscape. In this section, we will draw on small pieces of the vast literatures with which we engaged in relation with relationships, communication, and technology in schools, and then we will move to situate this chapter theoretically. 


\section{Awakening to the Complexities of Fostering Relationships Through Communication, and Technology}

Drawing toward relationships. Miller Marsh and Turner-Vorbeck (2010) published (Mis)Understanding Families: Learning from Real Families in Our Schools, in which they noted the scarcity of research attentive to examining "representations of families in schools" (p. 1), and the need for critical examination of "representations of families and appl[ying] that information to forging stronger, more successful relationships among families and educators" (p. 1). And yet, in a one-time survey of 127 early career teachers in the New York area, Horne (2010) found that "many beginning teachers report struggling in building relationships and communicating with parents" (p. 20).

Kim et al.'s (2012) review of numerous studies showed the need to be clear about ways language may shape interactions between teachers and families. Foregrounded in Kim et al.'s work is an emphasis on the need for family-school partnership models, which they understand as emerging in the research literature in response to "the limitations associated with unidimensional (school or home) or unidirectional (school to home) models" (p. 3). For Kim et al., family-school partnership models enhance "the bidirectional relationship between families and schools" (p. 4), and draw attention to "relational components ... [such as] creating a welcoming school environment" (p. 7).

In addition to Kim et al. (2012), Reschly and Christenson (2012) emphasize a systemsecological orientation to interactions between teachers and families as "partnerships require engaged relationships between families and educators" (p. 65), in order to "systematically remove barriers between families and educators by ensuring an ongoing process to identify and recommend constructive suggestions for improvement in the family-school interface rather than assigning blame" (p. 68). In an earlier review of family-school partnerships, Christenson (2004) highlighted how "trust building between home and school often runs counter to practices in schools where quick and efficient solutions are sought" (p. 96), and that "in many circumstances, efficiency is valued over the interaction process that requires time to build trusting relationships and get to know one another" (p. 96).

Hadley (2012), wanting to understand the kinds of experiences valued by families and staff in five day care settings in Australia, surveyed 58 families and 22 staff with the results showing that "although schools now invite families in, the ideology has not changed" (p. 39); that is, staff in schools, which also includes day care settings, are still positioned as "informing" families about school programming.

Klassen-Endrizzi and Smith (2004) foregrounded the difference between teachers "talking with parents" (p. 330) and teachers "talking at parents" (p. 330) in ways that supported more relational interactions. They noted that in their study "parents heard for perhaps the first time how teachers valued their years of learning with their child" (p. 330). Also noted, however, were complexities of "finding the time and energy to engage in these discussions" (p. 330). Klassen-Endrizzi and Smith (2004) closed their article with the recommendation that "teachers have a responsibility to start talking with the public by inviting families into discussions about learning. Parents are vital constituents many teachers overlook" (p. 332).

What we gradually came to understand in lingering in the literature was that although relationship-building with families has become a stated goal, the ways in which trust and 
relationship are sought, formed, and sustained are woven with complexities. In order to wonder further with these complexities, we then moved to wonder with how teachers, schools, parents, and families interact.

Lingering with the complexities of communication and technology. While digital platforms and communication technologies are often presented as potentially beneficial in communicating with parents, Keller (2008) wondered about the impact of their use on teacher workload. She writes about one school district in particular where the teachers' union developed "rules for email" (p. 15) as a way to support teachers in response to the increase in time and in response to teachers who were feeling bullied by parents via these platforms. Based on all of this, Keller recommended that early in the school year clear expectations be established for parents in relation with teacher and/or school communication. Also suggested was the development of web sites to communicate information with parents.

Thompson, Mazer, and Flood Grady (2015) examined the technological modes of communication parents choose to communicate with teachers, as well as if parents use different modes for differing kinds of communication. They found that "smartphones have affected how parents and teachers communicate, suggesting that parents view academic support and new communication technologies as important to their child's education" (Thompson, Mazer, \& Flood Grady, 2015, p. 202). While most parents in the study reported preferring email communication instead of modes such as texting, they noted the nature and complexity of the issue at the center of the communication should shape the choice of type of communication. In this article, aspects such as timeliness, accuracy, accountability, and accessibility were cited as reasons for the increasing the parents' preference for email communication.

Additionally, Jackson (2013) argued for technological "tools" to engage and bring families "into" the classroom in virtual ways. Recognizing the opportunity that technological platforms afford teachers (and children, and thus by extension parents and families) which they have not had in the past, Jackson suggested blogs and Twitter as "outreach" (p. 68) mechanisms for "digital family engagement" (p. 69).

This brief sketch of the research landscape supported us in our wondering deeply with the stories shared with us by the participants, in relation to how these early-career teachers experienced interacting with parents and families via a variety of digital platforms, and drew us to wanting to think narratively with the stories and wonders they had foregrounded for us.

\section{Thinking Narratively}

Though the original study in which Mrs. Lee, Dawn, and Sandra participated was not a narrative inquiry, the co-researchers carefully designed the semi-structured interview protocol to be attentive to what Connelly and Clandinin (2006) identify as the "commonplaces of narrative inquiry," (p. 479) which are temporality, sociality, and place. When describing the commonplace of temporality, they noted that "events ... under study are in temporal transition. Narrative inquirers do not describe an event, person, or object as such, but rather describe them with a past, a present, and a future" (p. 479). As narrative inquirers also attend to sociality, they attend to both personal conditions, as well as social conditions:

By personal conditions we mean the feelings, hopes, desires, aesthetic reactions, and moral dispositions of the person... By social conditions we mean the existential 
conditions, the environment, surrounding factors and forces, people and otherwise, that form the individual's context" (Connelly \& Clandinin, 2006, p. 480).

Place, as another commonplace of inquiring narratively, refers to "the specific concrete, physical, and topological boundaries of place where the inquiry and events take place. The key to this commonplace is the importance of recognizing that all events take place some place" (p. 481).

Clandinin and Connelly (2000) first conceptualized and described the "metaphorical three-dimensional narrative inquiry space" ( $\mathrm{p}$. 50) that is shaped through attending to the commonplaces of narrative inquiry, and they named this process "thinking narratively" (p. 34). We, as co-researchers in the study, additionally drew on Morris' (2002) understanding of thinking with stories:

The concept of thinking with stories is meant to oppose and modify (not replace) the institutionalized Western practice of thinking about stories. Thinking about stories conceives of narrative as an object. Thinking with stories is a process in which we as thinkers do not so much work on narrative ... [but allow] narrative to work on us. (p. 196)

To think and inquire narratively, then, in our understanding was to allow the stories to work on us within the metaphorical "three-dimensional narrative inquiry space... with the directions this space allows our inquiries to travel - inward, outward, backward, forward, and situated within place" (Clandinin \& Connelly, 2000, p. 49). Clandinin and Connelly (2000) described these four directions as follows:

By inward, we mean toward the internal conditions, such as feelings, hopes, aesthetic reactions, and moral dispositions. By outward, we mean toward the existential conditions, that is, the environment. By backward and forward, we refer to temporality - past, present and future. (p. 50)

Thinking narratively is a way of engaging with lived and told stories, that serve "as a starting point for exploring the many other stories that live in and around ... [them] and make up a life" (Downey \& Clandinin, 2010, p. 389). Furthermore,

To inquire narratively is to focus on experience as stories lived and told with an understanding that uncertainty lives in and between the situations or lived and told stories. Concretely this means focusing out from any one situation to see peripherally the many other situations that compose a life (Bateson 1994). The process of looking across the many stories that compose a life fosters its own form of unexpectedness, one brought on by seeing not only how we have gone about composing a life, but also how we might now go about composing it differently. (Downey \& Clandinin, 2010, p. 390)

As we returned to Mrs. Lee's, Dawn's, and Sandra's transcripts we did so thinking narratively, attending to the stories they shared of making their lives in and outside of schools, prior to, during, and following their preservice teacher education. Doing so, invited us to attend to how each had and is composing her life, and the multiple experiences each drew on as she interacted with, as she imagined future interactions with, families. 


\section{Narratively Inquiring Into Tensions}

As we became immersed in our inquiry, we found theoretical grounding in Clandinin and Connelly's (1995) conceptualization of teachers' professional knowledge landscapes, which they described as having "two different epistemological and moral places: in-classroom and out-ofclassroom places" (p.14). Within this context:

In-classroom places are described as safe places where teachers live out their personal practical knowledge (Connelly \& Clandinin, 1988), that is, their stories of who they are and who they are becoming as they interact with children. Out-of-classroom places are described as prescriptive, professional places shared with other teachers where teachers are expected to hold certain, expert knowledge shaped by policies, theories, and research, and given to them through dominant stories of school. (Clandinin, Murphy, Huber, \& Orr, 2010, p. 82)

As Clandinin, Connelly, and others continued to inquire into teachers' professional knowledge landscapes, attention turned to the tensions experienced by teachers as they navigated in and between the in-classroom and out-of-classroom places on their professional knowledge landscapes (Clandinin \& Connelly, 1995, 1998, 2000; Clandinin et al., 2006; Clandinin, Murphy, Huber, \& Orr, 2010). By thinking with the research literature alongside excerpts from the interview transcripts with Mrs. Lee, Dawn, and Sandra, we began to sense that their tensions often emerged as they crossed the boundaries between in- and out-of-classroom places. We noted, for example, that the reciprocal, relational relationships with families that the teachers were striving for in their in-classroom places sometimes bumped against division-wide policies prescribed in their out-of-classroom places, which mandated the use of specific digital learning platforms.

Our inquiry was additionally supported by the metaphor of the conduit, conceptualized by Clandinin and Connelly (1995) to represent the unidirectional transmission of knowledge into schools, packaged in the form of policies, instructional programs, staff meetings, workshops, and the like. According to Clandinin and Connelly (1995), this knowledge is typically "prepositional, relational among concepts, impersonal, situation-independent, objective, nontemporal, ahistoric, and generic" (p. 15), and moreover, "nothing comes through the conduit as merely theoretical knowledge to be known and understood; it always comes as an implied prescription for teachers' actions" (p. 14). There is little dispute that tensions arise for teachers as they carry knowledge from the conduit to their in-classroom places, where its implied prescriptions for their actions often bump against the teachers' knowledge and understandings of the children, youth, and families they are alongside in any given school year. While these tensions are often left unexplored, we sense it is profoundly pedagogical, as well as educative, to inquire into tensions experienced by Mrs. Lee, Dawn, and Sandra as they interacted with families in their inclassroom places using communication technologies that had been mandated in their out-ofclassroom places. As Clandinin et al. (2010), state:

For many teachers, and indeed for many people, tensions are thought to have a negative valence, that is, tensions are something to be avoided or smoothed over. If there are tensions evident in a school it is usually seen as a problem... Gradually, we began to understand tensions in a more relational way, that is, tensions that live between people, 
events, or things, and are a way of creating a between space, a space which can exist in educative ways. (p. 82)

\section{The Danger of a Single Story}

While some research literature attends to the tensions that communication technology raises for teachers, other research literature attends to ways the variety of online programs, applications, and digital learning management systems currently available to teachers enhances their ability to interact with children, youth, and families. Despite the multiple perspectives presented in the research, over the course of our conversations with each other as co-researchers, we came to sense there is a pervasive societal and institutional story that the use of digital platforms and communication technologies is an effective way to enhance interactions between teachers and families because they "provide teachers with a means to more easily communicate and share information with students and parents through discussion forums, social media, videoconferencing, email, grade books, and announcements" (Howell \& O'Donnell, 2017, p. 28). Our conversations were often drawn to wonder with our sense of the pervasiveness of this story of digital platforms and communication technologies as "making things better."

During these conversations we were reminded of Adichie's (2009) TedTalk, “The Danger of a Single Story," and her observation that "the single story creates stereotypes, and the problem with stereotypes is not that they are untrue, but that they are incomplete. They make one story become the only story" (para. 42). The danger of a single story, according to Adichie, is that it "flattens" experience by overlooking the many other stories that make up a person or a place. As we thought with Adichie's TedTalk alongside the stories Mrs. Lee, Dawn, and Sandra had told of their technology-mediated interactions with families, we were awakened to the multiplicity and complexity of their experiences, and to how their experiences could be flattened by a possible single story of technology as good. We were, however, also mindful to not begin composing a different single story as we attended closely to the multiplicity and complexity of Mrs. Lee's, Dawn's, and Sandra's experiences.

\section{Dwelling in the Tensions of Stories of Experience}

As we wondered how to represent some of the stories of experience shared by Mrs. Lee, Dawn, and Sandra, which at times appeared across multiple pages or reappeared in differing places in their transcripts, we were inspired by Butler-Kisber's (2002) practice of drawing on "the words of the participant(s) to create a poetic rendition of a story," particularly when "bits and pieces... [are] scattered over" (p. 232) or across a transcript. We have chosen to use found poems (Butler-Kisber, 2002; Richardson, 1997), composed from words spoken by Mrs. Lee, Dawn, and Sandra throughout this chapter. As we composed and as we read, and reread, these found poems, Richardson's (1997) sense that found poems have the ability to "re-create lived experience and evoke emotional response" (p. 521), and Butler-Kisber's (2002) sense that found poems can "be a way of representing holistically what might otherwise go unnoticed" (p. 235) deeply resonate with us. The following poetic renditions make visible some of the tensions that arose for Mrs. Lee, Dawn, and Sandra, and they supported us to narratively inquire into the teachers' experiences of tension. 


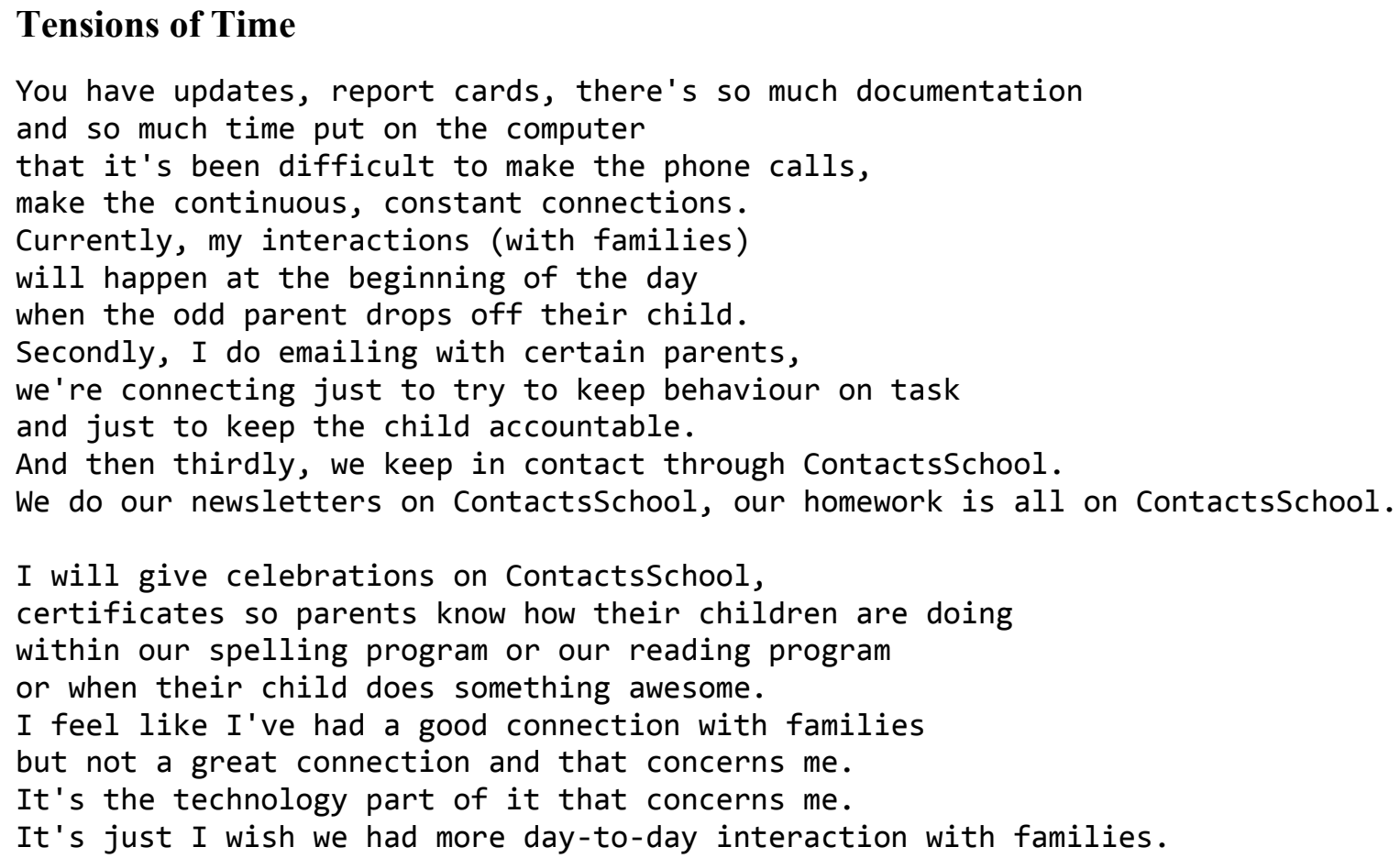

At the time of her interview, Mrs. Lee was returning to teaching after 14 years of being a stay-at-home mom with three children. As she shared childhood memories of interactions between her teachers and her mother, Mrs. Lee seemed to awaken to a sense that "I am who I am because of where I was coming from.". Mrs. Lee remembered her mother being highly and respectfully engaged in interactions with her teachers as she advocated for her daughter throughout Mrs. Lee's schooling. We sensed these memories drew Mrs. Lee's thoughts not only in a backward direction but also in forward and inward directions, toward memories of interactions she had had with her own children's teachers and schools. Mrs. Lee shared feelings of disconnectedness with her children's schools and teachers, and she shared tensions she was particularly experiencing in relation with her oldest daughter's high school because "everything is done by computer." We wondered how Mrs. Lee's childhood experiences and her experiences as a mother interacting with her children's teachers shaped the tensions she was presently feeling in relation with the interactions and connections she had with the families she was alongside as a teacher.

Mrs. Lee vividly remembered her first year of teaching and fondly recalled becoming very close with the families. As we read stories in Mrs. Lee's transcript about the many families who attended her wedding, we began to sense the importance of relationships to Mrs. Lee. We also sensed her tension with ways that teachers presently interacted with families compared with ways teachers interacted with families when she first began teaching 14 years earlier. She shared, for example, that her present interactions with families were rarely face-to-face now that few parents dropped off or picked up their children from school, and those who did were met by locked doors due to school safety policies. Mrs. Lee described email as some parents' main mode of communication, but how, as a teacher in a high needs Grade 2 classroom, she had tensions with email because it created a response-time expectation that she could not meet. She also expressed a desire to give her personal cell phone number to families, which would facilitate 
more in-time communication with them via text messages, but worried about possible repercussions. Although Mrs. Lee shared that she prefers telephone conversations with families because they are a more relational and reciprocal form of communication, she also experienced tensions with them, which she believed would be less acute with face-to-face interactions. She associated these tensions to English language barriers faced by many of the families who are newcomers to Canada and, additionally, she has learned that many of the families have past negative experiences of phone calls from school.

It was not difficult for us to sense connections between Mrs. Lee's deep desire for relational ways of being alongside families and her diverse experiences of interactions between families and teachers across time, place, relationships, and situations. We sensed the experiences which shaped and reshaped Mrs. Lee's desire for reciprocal and relation interactions with families also shaped her tensions with the use of technology to interact with families. We sensed she was agentically seeking ways to interact relationally with families by using the division's mandated digital learning platform, but in ways to celebrate children's successes at school, but she was feeling like this was not enough to facilitate and nurture the kinds of reciprocal relationships she was longing to have with families. While Mrs. Lee storied that she worried that these digital interactions were actually barriers to the more personal, relational, and reciprocal interactions she wanted to have with families because they were so time consuming.

\section{Expectation and Collegial Tensions}

It took me a long time to get my BEd degree;

it took me almost 10 years to finish it off

and so my youngest child when he was in Grade 4

had a teacher who emailed me every day,

emailed me what he had for homework and

I loved it. Absolutely loved it.

And that was something that was a real eye opener to me

'cause he knew I physically couldn't get into the school, couldn't pick up my son,

I couldn't talk to him and I couldn't touch base and he made that effort.

I've had families come back to me after their child has moved on and say

"You know, we appreciate the communication."

And I say, "I get it. I get it from a parent's point of view.

You have to work, that's just the way things are,

but you love your kid and you still want to be involved,

and that what I try to do. I try to bridge that gap."

I'll get emails at 10 o'clock at night, I'll get emails on the weekend, I'll get emails all the time.

A lot of the teachers at our school are younger

and a lot of them don't have children and

they have a very different perspective on things.

I find if I talk to them, they think I'm crazy anyways.

They think I'm crazy that I communicate that much with parents.

(Interview with Dawn)

At the time of her interview, Dawn was teaching Grade 1 at a school she described as " $80 \%$ families who have immigrated to Canada." Dawn was in the fifth year of her teaching career, and before that she had worked as an educational assistant in public schools and with a program called Getting Ready for Inclusion Together, in which she worked with children living 
with multiple disabilities in their homes. Dawn shared stories of how these experiences had taught her the importance of communicating clearly and openly with families, and she additionally acknowledged ways her experiences as a foster parent, participating in training sessions and interacting with biological families, taught her the importance of respectful and non-judgmental communication. It was, however, Dawn's remembered experiences of completing her Bachelor of Education degree while her three children were in elementary school that most significantly shaped her commitment to interact with families who do not and/or cannot come to the school for face-to-face interactions. This commitment is visible in Dawn's practice of extensively communicating with families via email and with a blog and photo sharing site that she shares with the other Grade 1 teacher at her school. As Dawn's found poem illustrates, she understands from her own experiences as a preservice teacher with school-age children, that not all parents are able to come to school to have conversations with their child's teacher. She credited her son's Grade 4 teacher with teaching her that even when a child's family members cannot interact with her in person, she can still have meaningful communication with them via email and other communication technologies.

Dawn mindfully uses email to pass on information to families in ways that facilitate interaction not only between herself and family members, but also between the children she teaches and their family members. She described, for example, sending a weekly mass email with information about the upcoming week; a Friday email to each family with the weekly sight words their child read correctly and ideas that might help them with the ones they are still learning; a mass email at the beginning of every 6-week unit explaining to families what their child will be learning and areas where they can support their child; and end of day emails, when appropriate, to share a photograph or something exciting that happened at school to generate conversation at home. Dawn saw communication technologies as having the potential to build bridges between children's lives at school and their lives at home with their families, and she hoped these bridges could support meaningful and relational interactions between children and their parents. We saw in Dawn's interview transcript many examples of the relational ways she lived her teaching practice alongside both children and families, including her invitation to families to email her any day and time with questions and/or concerns and her commitment to respond in time to their emails. We sense Dawn's used email not just to communicate with families, but also to co-build relationships with them.

Dawn's positive experiences alongside her son's Grade 4 teacher, who had sent her daily emails, planted the seeds for her commitment to regularly reach out to families through email. Then, as a teacher interacting with families, Dawn had experienced their expressions of appreciation for her regular and meaningful email communication with them, and this seems to have further strengthened her commitment. Although the technology-mediated interactions between Dawn and families are not, themselves, sources of tension in Dawn's storied experiences, tensions did surface when Dawn was asked if and how her school's culture and her colleagues supported her to interact with families. While Dawn was not critical of her colleagues, she noted that they did not communicate with families as often and as much as she did, and they questioned why she invested so much time and energy into emailing families. She noted, in particular, that her colleagues seemed to have tension in relation with her practice of emailing with families at any hour, when many of them did not respond to emails from families after 5:00 pm. Given that Dawn taught Grade 1, we wonder if some of her colleagues were concerned that as children move on to their classrooms in subsequent grade, they will not be able to maintain the 
same level of communication that families have become accustomed to with Dawn. As teachers come to their teaching practices with different experiences, different values and priorities, different demands on their time, and different knowledge and skills in relation with communication technologies, we continued to wonder with our understandings of the tensions between and among teaching colleagues that might surface.

\section{Tensions Around Professional Agency}

Technology-wise, I've been using ContactsSchool, although I've looked at my stats of parents who are actually using ContactsSchool and it's extremely low. I guess it's because we have such a high ESL population.

I stopped using ContactsSchool now because I realized no one's reading it.

So I have gone back to handing out newsletters in paper

to parents at the beginning of the month

with a calendar of all of our important dates, and then in their agendas I have labels or stickers because the kids can't write, just updating them of what's going on in the classroom.

I've started texting with some parents, which I didn't mean to do, it just happened by chance.

One of them is a very supportive family, the mom just wants to have updates, and it's easy for me to text and it's just how that worked.

So that's kind of new technology for me, too.

It's the first year I've given my phone number out.

I might regret it later.

We'll see.

(Interview with Sandra)

At the time of her interview, Sandra had been teaching for three-and-a-half years at the elementary level, and was both a Kindergarten teacher and the ESL lead teacher in her school. Early in her interview transcript, we noted how Sandra's childhood experiences alongside parents who were learning English seemed to shape the empathy she presently carried for families at her school who were newcomers to Canada. She recalled how her parents would have liked to be volunteers on class field trips or be involved in her school's parent council, but they both needed full-time jobs to support Sandra and her three sisters, and how they also felt that their English was not good enough. We wondered how Sandra, as a child, perceived her parents' lack of interaction at her school, and if she felt somewhat protective of her parents, who she knew cared deeply about her and her sisters' education even though they did not have a presence in their school. We also wondered how her teachers might have interpreted her parents' absence from the school landscape. This wonder emerged as we thought with Sandra's more recent stories of her interactions, as a teacher, with parents of children in her class who are learning English as adults, as her parents had. In these stories, Sandra shared how she mindfully looks for roles and volunteer activities for parents who are just learning English, and how "finding them different places in the school to get involved is the first step of making them realize that they're welcome here" (Interview with Sandra). 
We were particularly drawn to Sandra's decision to no longer use the digital learning platform prescribed by her employing school division to communicate with the families she was alongside for that school year. Sandra knew that the families were not using ContactSchool, and she imagined it was because they did not have access to the internet and/or their English language skills were a barrier to understanding the posted information. Similar to Mrs. Lee, Sandra experienced tension around the amount of time it took for her to keep the mandated digital learning platform updated for her class, and this tension increased when Sandra learned that the families were not reading the information. We sensed, however, that Sandra's desire for reciprocal and relational interactions with families and her realization that ContactsSchool was not supporting those relationships, was also a significant source of tension. We were moved by the agency that Sandra exercised to switch to paper newsletters and calendars that made use of symbols which parents could understand when they were not yet able to read English. Sandra mindfully chose, in her in-classroom place, to interact with families in ways that differed from policies mandated in her out-of-classroom places, and we wonder how her sense of agency might have been shaped by her childhood experiences. We sense both her childhood experiences and her experiences as an ESL lead teacher in her school have supported Sandra's understandings of the wholeness lives, and of ways diverse lives can sometimes bump against dominant school narratives.

Sandra's story of her decision to share her personal cell phone number with some parents surfaced another school narrative, which created tension for her as she crossed the boundaries between her in- and out-of-classroom places. Throughout her interview, Sandra wondered about the metaphorical line between professional and unprofessional behaviour in the teaching profession. Sandra remembered, for example, the tensions that emerged for her when she was invited by families to attend social events, such as a child's birthday party, and how she wanted to go for the child and family, but was worried that her colleagues might consider her attendance unprofessional. In a similar way, she worried about the sharing of her personal cell phone number with the parents of the some of the children in her class. While Sandra understood this sharing to be part of a relational way of being alongside families who preferred to communicate via text messaging, she also worried that she might "regret it". Sandra has helped us to further wonder how teachers' interactions with families are shaped by narratives of what constitutes professional behavior, and what those narrative might shape for teachers, like Sandra, who choose to dwell in the midst of the tensions that often arise when they reach for more reciprocal and ethical relationships with families.

\section{Resonant Threads: Weaving Tension and Possibility}

When Mrs. Lee, Dawn, and Sandra were asked to describe ways they presently interact with families via technology, they shared stories of using emails, texts, digital learning management systems, blogs, videos, and a variety of social media platforms. As their thoughts lingered with these experiences, their stories began to include multilayered and situationally diverse complexities and tensions, many of which we sensed arose as they crossed the boundaries between their in- and out-of-classroom places. While some of their stories highlighted the fact that technology enabled increased accessibility between families and teachers, other stories highlighted their tensions at feeling expected to respond promptly to electronic communications both during and beyond the school day or, in Dawn's case, feeling judged by colleagues who thought she responded too promptly. In lingering with these complexities, we began to wonder how teachers' and families' interactions with each other, both with and without the use of 
technology, might be shaped if preservice, in-service teachers, children, parents, and families were invited into the conversations that shape the policy and program development that school divisions enact.

\section{Institutional Narratives and Engagement}

Dwelling in the midst of these tensions, we returned to wonder with, what we had come to sense is, a dominant institutional narrative that technology improves communication and positively shapes interactions between teachers and families. We also wondered about the educative (Dewey, 1938) possibilities that might be opened up when relational interactions between schools, teachers, and families are drawn upon to shape the use of technology, as we noted in Sandra's story. These wonders brought us to consider who has typically shaped the decisions made as to which digital platforms are privileged, how those decisions get translated to teachers via the metaphorical conduit in relation with how these platforms are to be used, and which are not to be used. What might be possible if the conduit was inverted? What if children, parents, and family members were to be called upon as knowledge-holders with whom to collaborate and from whom to learn? What if children and families felt agentic in shaping the conversation around communication and interactions with teachers? What if teachers felt agentic in deciding what best supports their interactions with the children and families they are alongside? We wondered about the educative potential of such an inversion of the conduit, and the possibilities such collaborative decision and policy making might open.

These wonders drew us toward literatures that also wondered with the inclusion (or exclusion) of parental/ familial knowledge in shaping the interactions schools and teachers have (or are not having) with families. For example, drawing on experiences in a project focused on parent knowledge and engagement, Pushor and Ruitenberg (2005, with co-researchers) distinguished between the terms "parental involvement" and "parental engagement" by noting how "participation . . . implies that parents actually ... have a right to be included, whereas someone who is involved is there by invitation" (p. 6). Seeing "parental involvement" as "activities in which parents are invited to serve the school's agenda, to do the things educators deem important" (p. 6), Pushor and Ruitenberg (2005) conceptualized "parental engagement" as parents taking a "place alongside educators in the schooling of their children, fitting together their knowledge of children, teaching and learning, with teachers' knowledge" (pp. 12-13). Parent engagement, then, can be understood as opening possibility "for the structure of schooling to be flattened, power and authority to be shared by educators and parents and the agenda being served to be mutually determined and mutually beneficial" (Pushor \& Ruitenberg, 2005, pp. 1213). We continue to wonder how much or how often communication via digital platforms is information-driven, with the intention of one-way communication of information, dates, events, etc. to parents and families, which would resonate with Pushor and Ruitenberg's sense of involvement, and we also continue to wonder with how digital platforms might be understood as ways to shape engagement in Pushor and Ruitenberg's understanding.

\section{Lingering Wonders}

As we continue to think with the teachers' stories, which foregrounded the tensions in the "single story" (Adiche, 2009) of communication technology as a singular solution to communicating/interacting with families, we came to wonder about the connections with teacher education, both preservice and in-service. We came to wonder about the opportunities for inquiry 
that the semi-structured interviews opened in which the beginning teachers shared how they were awakening to their interactions with families as also having been profoundly shaped by their personal experiences as youth, and for some as parents themselves. We now wonder about the possibilities that might be opened in preservice and in-service teacher education if there were places and spaces to support similar inquiry, awakenings, and knowing. We wonder about the opportunities in pre- and in-service teacher education for careful consideration of the nested complexities of communication via digital means. We wonder about the opening of spaces for conversations about and around digital communication platforms and the agency teachers, children, youth, and families have in those decisions, and again how shaping spaces and places in teacher education to begin to wonder with preservice teachers' experiences narratively might support teachers to think more deeply with these complexities.

Our literature review foregrounded not only the draw toward increased reciprocal and relational interactions with parents and families in schools, which was widely supported by the participants in our study, but also the complexities that surface in relation with communication, engagement, involvement, and technology. We sense that much more work is needed to support preservice and in-service teacher education programs to engage with this wonder. Mrs. Lee, Dawn, and Sandra opened a space in which they (and we) could think with their experiences across time, places, and in a variety of situations and relationships, alongside their respective preservice teacher education programs. What we came to sense was a gap; each storied that in their pre- and in-service teacher education, digital platforms and communication technologies had not been an aspect considered in conversations connected with building relationships with parents and families.

We slowly came to sense the far-reaching possibilities of shaping places for these kinds of conversations and think kind of inquiry, grounded in experience, in teacher education. And while we wonder about the relationships teachers are imagining having and building with children and families, we also wonder about the relationships and interactions families are imagining having with teachers and schools. We also wonder, with a profound sense of possibility and awe, what might shift and change if preservice teachers, children, youth, parents, and families were drawn into these important conversations as "holder[s] and maker[s] of knowledge" (Connelly \& Clandinin, 1999, p. 1). We wonder if and how they might sense that they were being encouraged to "reflect on things as if they could be otherwise" (Greene, 2001, $p$. 98), and if these reflections might draw closer to the reciprocal and relational interactions that Mrs. Lee, Dawn, and Sandra were imagining in their becoming as teachers.

${ }^{1}$ All names reflect the pseudonyms each early career teacher chose for themselves.

${ }^{2}$ The name of the platform has been fictionalized so as to maintain participants' anonymity

${ }^{3}$ The ways in which participants were invited to the study depended on each individual school district's policies.

${ }^{4}$ Please see the section entitled Thinking Narratively for a detailed description of our understanding of what thinking narratively entails.

\section{References}

Adichie, C. N. (2009). The danger of a single story [Annotated Video Transcript]. Retrieved from http://www.ted.com/talks/chimamanda_adichie_the_danger_of_a_single_story.html 
Butler-Kisber, L. (2002). Artful portrayals in qualitative inquiry: The road to found poetry and beyond. Alberta Journal of Educational Research, 48(3), 229-239.

Christenson, S. L. (2004). The family-school partnership: An opportunity to promote the learning competence of all students. School Psychology Review, 33(1), 83-104. Retrieved from http://login.ezproxy.library.ualberta.ca/login?url=http://search. ebscohost.com $/ \operatorname{login}$. asp $x$. direct $=$ true $\& d b=$ ofs $\& A N=507874797 \&$ site $=$ eds$\underline{\text { live } \& \text { scope }=\text { site }}$

Clandinin, D. J., \& Connelly, F. M. (1995). Teachers' professional knowledge landscapes. New York, NY: Teachers College Press.

Clandinin, D. J., \& Connelly, F. M. (1998). Stories to live by: Narrative understandings of school reform. Curriculum Inquiry, 28(2), 149-164.

Clandinin, D. J., \& Connelly, F. M. (2000). Narrative inquiry: Experience and story in qualitative research. San Francisco, CA: Jossey-Bass.

Clandinin, D. J., Huber, J., Huber, M., Murphy, M. S., Orr, A. M., Pearce, M., \& Steeves, P. (2006). Composing diverse identities: Narrative inquiries into the interwoven lives of children and teachers. London, UK: Routledge.

Clandinin, D. J., Murphy, M. S., Huber, J., \& Orr, A. M. (2010). Negotiating narrative inquiries: Living in a tension-filled midst. Journal of Educational Research, 103(2), 81-90.

Connelly, F. M., \& Clandinin, D. J. (1999). Shaping a professional identity: Stories of educational practice. New York, NY: Teachers College Press.

Connelly, F. M., \& Clandinin, D. J. (2006). Narrative inquiry. Handbook of complementary methods in education research, 3, 477-487.

Dewey, J. (1938). Experience and education. New York, NY: Collier Books.

Downey, C. A., \& Clandinin, D. J. (2010). Narrative inquiry as reflective practice: Tensions and possibilities. In Handbook of reflection and reflective inquiry (pp. 383-397). Boston, MA: Springer.

Greene, M. (2001). Variations on a blue guitar: The Lincoln Center Institute lectures on aesthetic education. New York, NY: Teachers College Press.

Hadley, F. (2012). Early childhood staff and families' perceptions: Diverse views about important experiences for children aged 3-5 years in early childhood settings. Contemporary Issues in Early Childhood, 13(1), 38-49. Retrieved from http://login.ezproxy.library.ualberta.ca/login?url=http://search.ebscohost.com/login.aspx? direct=true \&db=eric\&AN=EJ969649\&site=eds-live\&scope $=$ site

Horne, E. T. (2010). The contribution of teachers' roles to beginning teachers' perceptions of success. Raleigh, NC: North Carolina State University.

Howell, S., \& O’Donnell, B. (2017). Digital trends and initiatives in education. Ontario Media Development Corporation. 
Huber, J., Reid, N., Farmer, J., Desrocher, C., \& McKenzie-Robblee. (2017). Interactions between early career teachers and families. Unpublished Report.

Jackson, C. (2013). Cool tools for back to school: Three digital tools are great ways to start engaging families and the community as the school year begins. Principal Leadership, 14(1), 68-69. Retrieved from http://login.ezproxy.library.ualberta.ca/login?url=http: $/ /$ search.ebscohost.com/login.aspx?direct $=$ true $\& d b=$ edsgao\&AN=edsgcl.349224304\&site $=$ eds-live $\&$ scope $=$ site

Keller, B. (2008). Schools seek to channel parent involvement. Education Week, 27(31), 1. Retrieved from http://search.proquest.com.login.ezproxy.library.ualberta.ca/docview/61949930?accounti $\underline{d}=14474$

Kim, E. M., Coutts, M. J., Holmes, S. R., Sheridan, S. M., Ransom, K. A., Sjuts, T. M., \& Rispoli, K. M. (2012). Parent involvement and family-school partnerships: Examining the content, processes, and outcomes of structural versus relationship-based approaches (CYFS working paper no. 2012-6). Retrieved from https://eric-edgov.login.ezproxy.library.ualberta.ca/?id=ED537851

Klassen-Endrizzi, C., \& Smith, K. (2004). We've got to talk: Redefining our work with families. Language Arts, 81(4), 323-333.

Miller Marsh, M., \& Turner-Vorbeck, T. (2010). (Mis)understanding families: Learning from real families in our schools. New York, NY: Teachers College Press.

Morris, D. B. (2002). Narrative, ethics, and pain: Thinking with stories. In R. Charon \& M. Montello (Ed.), Stories matter: The role of narrative in medical ethics (pp. 196-218). New York, NY: Routledge.

Pushor, D., Ruitenberg, C., with co-researchers from Princess Alexandra Community School. (2005, November). Parent engagement and leadership. (Research Report, Project \#134). Saskatoon, SK: Dr. Stirling McDowell Foundation for Research into Teaching. Retrieved from?

Reschly, A. L., \& Christenson, S. L. (2012). Moving from "context matters" to engaged partnerships with families. Journal of Educational \& Psychological Consultation, 22(1), 62-78. doi:10.1080/10474412.2011.649650

Richardson, L. (1997). Fields of play: Constructing an academic life. New Brunswick, NJ: Rutgers University Press.

Thompson, B. C., Mazer, J. P., \& Flood Grady, E. (2015). The changing nature of parent-teacher communication: Mode selection in the smartphone era. Communication Education, 64(2), 187-207. Retrieved from http://search.proquest.com.login 